Abstracta Iranica Abstracta Iranica

Revue bibliographique pour le domaine irano-aryen

Volume 31 | 2011

Comptes rendus des publications de 2008

«Étude sur une interprétation messianique du mouvement constitutionnel iranien ». Oriente Moderno, 88/1, 2008, p. 99-108.

Jean Calmard

CpenEdition

Journals

Édition électronique

URL : http://journals.openedition.org/abstractairanica/39596

DOI : 10.4000/abstractairanica.39596

ISSN : 1961-960X

Éditeur :

CNRS (UMR 7528 Mondes iraniens et indiens), Éditions de l'IFRI

Édition imprimée

Date de publication : 15 mai 2011

ISSN : 0240-8910

Référence électronique

Jean Calmard, « «Étude sur une interprétation messianique du mouvement constitutionnel iranien ». Oriente Moderno, 88/1, 2008, p. 99-108. », Abstracta Iranica [En ligne], Volume 31 | 2011, document 176, mis en ligne le 11 octobre 2012, consulté le 04 octobre 2020. URL : http://journals.openedition.org/ abstractairanica/39596 ; DOI : https://doi.org/10.4000/abstractairanica.39596

Ce document a été généré automatiquement le 4 octobre 2020.

Tous droits réservés 


\title{
«Étude sur une interprétation messianique du mouvement constitutionnel iranien $»$. Oriente Moderno, 88/1, 2008, p. 99-108.
}

\author{
Jean Calmard
}

Comme le signale D. Hermann, les recherches concernant les écrits des 'olamā pro ou anti-constitutionnalistes se sont essentiellement concentrées sur Nūrī (un «anti», m. 1909) et Nā'înī (un «pro ", m. 1936). Ceci est dû en partie à l'inaccessibilité des «traités» progressivement publiés depuis dix ans, signalés par l'auteur. Dans cet article, il étudie un court traité, Ehy $\bar{a}$ ' al-mellat, de ŠeyH Ḥoseyn Būšehrī (m. 1361/1922-3). En se basant sur des hadịt et des prévisions astrologiques célèbres (dont l'assassinat de Nāṣer-od-dīn Šāh en 1896 et l'avènement du parlementarisme), ce šeyH voit dans ces événements des signes annonciateurs de la parousie du Douzième Imam. Dans le futur gouvernement du messie, les constitutionnalistes devront lui transférer le pouvoir (p.100s.). Tout en soulignant le caractère surprenant de l'argumentation de Būšehrī, l'A. l'inscrit dans la rupture radicale marquée par le constitutionnalisme en Iran "qui ne marque pas en soi la fin de la dynastie qājāre " (p. 107). La publication de cet article est entachée par une erreur de la Rédaction qui, dans l'« Indice », l'attribue à « Denis Hartmann ».

\section{INDEX}

Thèmes : 4.3. Histoire de l'Iran moderne (à partir de 1905) 
AUTEURS

JEAN CALMARD

CNRS - Paris 